\title{
Application of doped-titanate nanotubes in (1) the photodegradation of Tannic Acid, Methyl Orange and Malachite Green and (2) the inhibition of bacteria and fungus .
}

\section{Research Article}

Keywords:

Posted Date: March 31st, 2021

DOI: https://doi.org/10.21203/rs.3.rs-353243/v2

License: (1) This work is licensed under a Creative Commons Attribution 4.0 International License.

Read Full License 


\section{Abstract}

The authors have requested that this preprint be withdrawn due to erroneous posting.

\section{Full Text}

The authors have withdrawn this preprint from Research Square. 